\title{
THE INFLUENCE OF ORGANIZATIONAL CLIMATE ON INNOVATIVE WORK BEHAVIOUR
}

\author{
Arum Etikariena, Shanindya Bias Imaji Kalimashada \\ Faculty of Psychology, Universitas Indonesia, Indonesia \\ Kampus Baru UI Depok - 16424 \\ arum.etikariena@ui.ac.id
}

\begin{abstract}
This study discusses about the effect of organization climate on innovative work behaviour. The respondents of this study were 124 employees who work in a mining company which implement innovation. This research was a quantitative research and used Innovative Work Behaviour Scale by Janssen (2000) and Organizational Climate Measurement by Patterson et al. (2005). The data analysis technique used multiple regression analysis. The result showed that there was an influence of organizational climate on innovative behavior in the workplace by $12.1 \%$, $R^{2}=.121 ; F(1,122)=16,721, p<.05$. The results also showed from the three dimensions of organizational climate, only two has significant effects, they are flexibility \& innovation, $t(120)=2.433, p<.05$, and outward focus, $t(120)=2.113, p<.05$. Dimension which not significantly affect innovation work behaviour is reflexivity, $t(120)$ $=-.143, p=.886$. The implications of this study can be considered by organizations to develop a supportive organizational climate so that employees feel comfortable to display innovative work behaviors and at the end will ultimately have a positive impact for the organization.
\end{abstract}

Keywords: organizational climate; innovative work behaviour; mining company

\section{INTRODUCTION}

Competition between companies these days are increasingly tight. This is supported by the rapid development of technology and information as well as the growth of consumer demands. To survive the competition, companies and organizations must be able to adapt and one of the ways to achieve this is through innovation (Cingöz \& Akdoğan 2011; Jiménez-Jiménez \& Sanz-Valle, 2011; Vinarski-Peretz \& Carmeli 2011). Companies can obtain many benefits through innovation, among others, companies can function more effectively (Janssen, 2000), organization competitiveness is maintained (Hammond et al., 2011), organizations can improve performance (Vinarski-Peretz \& Carmeli, 2011), and help companies gain an increase in profits (De Jong \& De Hartog, 2010). Various companies in the world encourage innovative behavior in their employees because employees play an important role in bringing innovation to life (Etikariena \& Muluk, 2014). Getz and Robinson (2003) mention that $80 \%$ new ideas come from individuals and only 20 $\%$ from organizational initiatives. There needs to be a special effort from the company to increase the willingness of its employees to be innovative, so that innovation can easily be supported. When a program is carried out properly, the benefit is not only for the company, but employees will gain benefits too, such as increased work satisfaction, additional incentives and improved skills. If they fail, the employees have lost nothing and simply carry on as before while trying to find new ideas.

Some experts are still debating this innovative concept (Potočnik \& Anderson, 2016). One important debate is related to whether innovation and creativity are the same thing or different. Amabile, (1996); Hennessey and Amabile (2010) say that these are two different things. The creative process involves the process of finding new ideas, but do not reach the implementation stage (Amabile, 1996). While innovation is defined as the generation and application of new ideas by individuals and other members of the organization because of the demands of the organization (Scott \& Bruce, 1994). Janssen (2000) points out that innovation is essentially an idea developed, brought about, and modified by individuals. Hence, it can be 
concluded that the basis of innovation are ideas. The idea comes from person who works in the company. If we want to learn about innovation, we should look at the person who carries out this innovation. Scott and Bruce (1994) were the first researchers that mention innovation at the individual level. They define innovative work behaviors as an intentional effort to generate, promote and implement ideas within the scope of tasks, workgroups, to provide benefits for organizations. This definition is used as the basis for the definition of innovative work behavior in this study.

Various efforts are made to develop innovative work behaviors, one of which is by understanding what factors play a role (Standing et al., 2016; Zennouche et al., 2014). The three main factors that influence innovation are internal, occupational, and contextual factors. Internal factors consist of individual differences, personalities, and motivation. There is also a role of selfmonitoring (Sulistiawan et al., 2017). Occupational factors consist of job complexity, job characteristics, and time pressure (Baumann, 2011; Etikariena, 2018; Hammond et al., 2011). At the level of work in groups, some factors include organizational team climate and characteristics of group members, at the organizational level such as culture, strategies, and structures, that affect the innovative work behavior of employees (Sameer \& Ohly, 2017). The last factor, contextual factors consist of support to innovate, organizational climate, availability of resources, leader-member exchange, transformational leadership, relationships at work, group factors, and organizational factors (Chih-Yang Chao et al., 2011; Hammond et al., 2011).

Of the factors mentioned above, this study will focus more on the role of organizational climate. The reason is because the organizational climate is a condition that has a positive influence on performance (Sethibe \& Steyn, 2016; Shanker et al., 2017). Appipalakul and Kummoon (2017) research for example also shows the importance of organizational climate to minimize conflicts while working. This is inseparable from the definition of the organizational climate, how an organizations members perceive their experience within the organization, then the members of the organization put a common meaning to the experience within the organization (Patterson et al., 2005). A new characteristic can be decided as an organizational climate when interpreted jointly by members of the organization. For example, one employee considers the organizational climate of the company as competitive, but the other employees consider the climate of the company as family, it can be concluded that the organizational climate of the company is competitive or familial.

When it comes to innovation, organizational climate is an important factor that contributes towards innovation. A positive organizational climate, such as one that is participatory, open, and safe, will motivate employees to demonstrate innovative behavior (Hammond et al., 2011). A positive organizational climate can influence innovative behavior by providing intrinsic motivation to employees and making employees feel fully supported by the company, so that employees do not hesitate to display innovative behavior (Shalley et al., 2004). However, studies on organizational climates still need to be developed, especially related to how the organizational climate dynamic impacts the performance of the organization, one of which is represented by innovative work behavior (Shanker et al., 2017). Therefore, it is important for companies to design a positive organizational climate and support employees to display innovative behavior because a positive organizational climate can be perceived as supportive and that the company pays attention to its employees, so that the employees are encouraged to demonstrate innovative behavior that can benefit the company. This is also supported by subsequent studies that found that organizational climate with different roles turns out to be related and influences 
innovative work behavior (Ahmed et al., 2019; Bogilović et al., 2020; Izzati, 2017).

Research conducted by Imran et al. (2010) state that Open System Model organizational climate will support employees to display innovative work behavior. Referring to the findings, this study will only use Open System Model from the four organizational climate models of Patterson et al. (2005). The selection of one of the four models is explained by Patterson et al. (2005) which states that it is best for researchers to choose one of the scales or quadrants that best matches the research being worked on. All models' application would indicate that a study is theoretically lacking in focus. There has been a lot of research to study innovative behavior in the workplace and even innovative words are considered overused terms in the United States (O'Bryan, 2013), but from the positive side, this can be seen as the increasing number of companies that realize the importance of innovation to face various challenges ahead. Participants of this study were employees working for a mining company. The mining industry has characteristics such as being located in a remote area because it is close to the mining site and produces large quantities of product to be exported to other countries. Innovations that generally occur in mining companies are in technology especially technology that is developed to mine, innovation is also needed to find locations that have potential to contain coal. As for the head office innovations that may benefit them are innovations in solving problems encountered daily in order to improve work performance. Based on this consideration, the researchers decided to conduct a study on mining companies to look deeper at organizational climate and its influence on innovative work behavior within the company. Based on the background description, the main issue raised in this study is whether there is an influence of the organizational climate on innovative work behavior on employees of PT X.

Quinn and Rohrbaugh (1983) compiled a model for researching the effectiveness of a company. The model called Competing Values Approach was later used by Patterson et al. (2005) as the basis for measuring the organizational climate of a company. Competing Values Approach consists of four models, one of which is Open System Model, (as used in this study), this model focuses on external factors, the customers. In addition, this model has a flexible organizational structure and has growth and resource acquisition goals. The goals are achieved by maintaining the flexibility and readiness of the company. Open System Model has three dimensions, flexibility \& innovation, outward focus, and reflexivity. Flexibility is the orientation to change, while innovation is the support of new ideas and approaches. Outward focus is a responsive organization to the needs of buyers and the market in general. Reflexivity is an attempt to broadly review the goals, strategies, work processes, and organizational environment (Patterson et al., 2005)

The definition of innovative work behavior is as follows:

“..., individual innovation begins with problem recognition and the generation of ideas or solutions, either novel or adopted. During the next stage of the process, an innovative individual seeks sponsorship for an idea and attempts to build a coalition of patsupporters for it. Finally, during the third stage of the innovation process, the innovative individual completes the idea by producing 'a prototype' or model of the innovation ..."

“... Innovation is viewed here as a multistage process, with different activities and different individual behaviors necessary at each stage" (Scott \& Bruce, 1994, pp. 581-582).

Scott and Bruce (1994) see innovation as a process with several different stages. The first stage is the process of problem recognition and finding solutions to the problem. The second stage, to find sponsorship to support 
the idea and then model the existing idea. The definition of Scott and Bruce (1994) was clarified by Janssen (2000), as a deliberate attempt to find, promote, and implement ideas within the scope of tasks, working groups, and organizations to provide benefits and merits to the organization.

Scott \& Bruce (1994) divide innovative work behavior into three different stages, idea generation, idea promotion, and idea realization. In idea generation, individuals are able to recognize problems, then create new ideas or solutions that are useful. The process that occurs at this stage is similar to that which occurs in the creative process. The next stage is idea promotion, where individuals promote ideas that have been created by colleagues so that they can be accepted. In addition, at this stage there is also a collection of support so that the idea has the power to be implemented. The last stage is idea realization, individuals produce prototypes or models of an idea to apply in the scope of work, group, or organization as a whole. These stages form innovative work behavior and cannot be interpreted separately so that the measurements are unidimensional. Therefore, this has an impact on the analysis based on the total score of these three stages (Scott \& Bruce, 1994). From the description of the phenomena and arguments presented above, the hypothesis which becomes the focus of this study is that there is a relationship between the organizational climate and innovative work behavior.

\section{METHOD}

This study uses two variables, organizational climate as a independent variable and innovative work behavior as a dependent variable. This is quantitative research with cross-sectional study design (Kumar, 2011). The target of this research were employees at a company that applies innovative values. Respondents to this study were employees working for a coal mining company located in East Kalimantan. In 2013, Fortune Indonesia magazine awarded PT $\mathrm{X}$ as one of the most admired companies in mining with one of the criteria being assessed is its innovation (Purwanto, 2013). PT $\mathrm{X}$ has the value of "Exponential spirit, encouraging us to always be innovative, future-oriented and proactive". It also has three philosophies, innovative, progressive, and trust (PT X Company Profile, 2013). Recognition from the public in the form of awards as well as philosophy and value that prioritizes innovative is a consideration for researchers to choose this company as a respondent. The sampling technique used was accidental sampling. Participants were employees who have worked for mining company for more than a year. The sample used in this study was 124 participants who were all permanent employees.

The measuring instrument used in this study was Organizational Climate Measurement by Patterson et al. (2005) consisting of 16 items. Measurements of innovative work behavior also vary (De Spiegelaere et al., 2014). This study used Innovative Work Behavior Scale developed by Janssen (2000) from Innovative Work Behavior Scale from Scott and Bruce (1994) as many as 6 to 9 items. This measuring instrument from Janssen was later adapted by Etikariena and Muluk (2014) into Indonesian, using a 6-point Likert type scale. The use of Likert type scale was to make it easier for participants to respond (SuárezAlvarez et al., 2018). Before administration, these instruments were tested first to see the reliability and validity of each instrument. The trial was conducted with a private company engaged in telecommunications.

Based on the calculation results, Cronbach's Alpha value for Innovative Work Behavior Scale is .936 and for Organizational Climate Measurement is .813. The coefficient of Cronbach's Alpha indicates that the measuring instrument has a high internal consistency. As for corrected item-total correlation on both scale is worth above .20 which means it has a fairly good item validity. Therefore, the items presented can be declared well filtered (Józsa \& Morgan, 2017). It is 
expected that the bias caused by reserved items also did not happen considering all items were favorable (Weijters et al., 2013). To minimize the common method bias, randomizing the items during administration was done so the respondents were unable to guess the direction of the study (Podsakoff et al., 2003). The data obtained by disseminating the questionnaire were analyzed using simple regression to see the effects given by organizational climate on innovative work behavior and multiple regression to see the effects given by dimensions of organizational climate on innovative work behavior.

\section{RESULT AND DISCUSSION}

The dissemination of questionnaires to collect data gained from 124 participants. The distribution can be seen in the table below:

Table 1.

Demographic Data of Respondents

\begin{tabular}{lcc}
\hline Category & $n$ & $\%$ \\
\hline Gender: & & \\
$\quad$ Male & 98 & 79 \\
Female & 26 & 21 \\
Age: & & \\
$\quad$ <25 & 20 & 16 \\
$25-44$ & 103 & 83 \\
$44-65$ & 1 & 1 \\
Education: & & \\
Senior High School & 7 & 5.6 \\
Diploma & 4 & 3.2 \\
Bachelor & 111 & 89.5 \\
$\quad$ Master or Doctorate & 2 & 1.6 \\
Tenure: & & \\
$\quad$ < 2 years & 27 & 21 \\
2-10 years & 92 & 74 \\
>10 years & 5 & 4 \\
Job Level: & & \\
Staff & 116 & 93.5 \\
Supervisor & 8 & 6.5 \\
Salary: & & \\
$\quad$ < 5 million & 9 & 7.2 \\
5-10 million & 56 & 45.2 \\
>10 million & 59 & 47.6 \\
\hline
\end{tabular}

From table 1 above, it can be seen that the respondents involved were dominated by 98 male respondents (79\%), age range of $25-44$ years and as many as 103 people (83.1\%), working period (within the company) with the majority between 2-10 years, 92 people (27.4\%), education with bachelor degree 111 people $(89.5 \%)$, staff level 116 people $(93.5 \%)$ and the highest salaries in the range of more than 10 million rupiahs per month as many as 59 people $(47.6 \%)$.

\section{Table 2.}

Simple Regression Analysis of Organizational Climate on Innovative Work Behavior

\begin{tabular}{lrc}
\hline & $b$ & $t$ \\
\hline Constant & 19.310 & 4.968 \\
OC & .261 & 4.089 \\
$r$ & \multicolumn{2}{c}{$.347^{* *}$} \\
$R^{2}$ & \multicolumn{3}{c}{.121} \\
$F$ & \multicolumn{2}{c}{$16.721^{*}$} \\
\hline
\end{tabular}

Note $. \mathrm{OC}=$ Organizational Climate.

${ }^{*} p<.05 .{ }^{* *} p<.01$.

Based on the data above, it can be seen that the value of $r=.347, p<.001$. This suggests that the research hypothesis, which is that there is a link between organizational climate and innovative work behavior, is accepted. The organizational climate significantly influences innovative work behavior within PT X with $F(1,122)=16,721, p<.05$. Then, based on its parameter model, it can be concluded that the organizational climate significantly has an impact on innovative work behavior. Furthermore, with the coefficient of $R^{2}$ as much as .121, this means that the organizational climate influences innovative work behavior by $12.1 \%$ and the rest, which is $87.9 \%$ is influenced by factors other than the organizational climate. Thus, the organizational climate contributes to the formation of innovative work behavior.

The second analysis is to see the influence of each dimension of organizational climate on innovative work behavior. This is because the organizational climate measurement tool is multidimensional, so that each dimension can be seen to have an influence on innovative work behavior variables. The organizational climate dimensions are flexibility and innovation, outward focus, and reflexivity. 
Table 3.

Multiple Regression Analysis of Organizational Climate's Dimensions on Innovative Work Behavior

\begin{tabular}{lccc}
\hline Organizational Climate Dimensions & $b$ & $t$ & $p$ \\
\hline Constant & 21.548 & 5.311 & .000 \\
Flexibility \& Innovation & .335 & 2.433 & $.016^{*}$ \\
Reflexivity & -.022 & -.143 & .886 \\
Outward Focus & .361 & 2.111 & $.037^{*}$ \\
\hline${ }^{*} p<.05$. & & &
\end{tabular}

Judging from its significance, flexibility \& innovation dimension has a value of $t(120)=$ $2.433, p<.05$; outward focus dimension has a value of $t(120)=2.111, p<.05$; and reflexivity dimension has a value of $t(120)=$ $-.143, p>.05$. This indicates that the flexibility \& innovation dimension and the outward focus dimension affect innovative work behavior at .05 level of significance. While reflexivity dimension is proven not to affect innovative work behavior.

Furthermore, the analysis was conducted for different tests with ANOVA analysis to see the difference in the level of innovative work behavior in each demographic category measured. As a result, based on gender, males $(M=34.96)$ had a higher innovative behavior scores than females $(M=35.19)$, but this difference was insignificant, $F(2,120)=$ $1.527, p>.05$. For age, the highest average score of innovative behavior is $45-65$ years old $(M=.46)$, but this difference was also insignificant, $F(3,119)=1.231, p>.05$. Based on the working period, the highest innovative behavior score were participants who were in the working period of 3-10 years $(M=35.81)$, this difference proved quite significant, $F(3,119)=2.838, p<.05$. Based on level of education, the highest average innovative behavior score was master level ( $M$ $=.44)$, this difference was also significant, $F(4,118)=4.501, p<.01$. Based on the position level, there was no significant average score difference between managers and non-managers, $F(2,120)=.004, p>.05$. For innovative work behavior scores based on salary, the highest average was held by participants with salaries above 10 million $(M$
$=.36)$, but this difference was insignificant, $F(3,119)=2.166, p>.05$.

The results of this study are similar with Ömur's study (2019) which found that the organizational climate influences innovative work behavior. A positive organizational climate will support innovative work behavior and vice versa, a negative organizational climate will also hinder the emergence of innovative work behavior. This is proven by the significant influence of organizational climate on innovative behaviors in the workplace. The model used in this study was the Open System Model, one of four models that existed in the concept of organizational effectiveness by Quinn and Rohrbaugh (1983). Companies that gain a high Open System Model score have characteristics of flexible organizational structure and focus more on organizational development than individual development, have a goal for organizational growth and are able to survive in their existing competitive fields (Quinn \& Rohrbaugh, 1983). This model also focuses on readiness, change, and innovation. The values and norms applied in this model are organizational growth, resource acquisition, creativity, and adaptation (Patterson et al., 2005). These findings are in line with Imran et al. (2010) research that say organizational climate Open System Model will support employees to display innovative work behavior. Increasingly intense global competition forces organizations to be flexible in dealing with external environments. One way that this can be done is to apply innovation and adapt to growing market trends so it can continue to grow constantly. This is also in line with studies by 
Chang et al. (2012) as well as Chen and Yin (2017) and conducted among students. The supportive climate will greatly allow individuals to display innovative behavior.

However, the effect shown by the organizational climate is around $12 \%$ which means it shows a relatively small effect. Therefore, considering the role of other variables as an antecedent or moderator or putting organizational climate in different roles, for example as a moderator is expected to strengthen the influence of antecedents on innovative work behavior. Bos-Nehles and Veenendal (2017) place the organizational climate as a moderator in the relationship between HR practices on innovative work behavior or look at the role of the organizational climate mediated leadership style on innovative work behavior (Sethibe \& Steyn, 2018). With a comprehensive model, it is expected that the organizational climate influence will be stronger and more comprehensive in explaining the emergence of innovative work behavior.

The next analysis is to look at the influence of each dimension with innovative work behavior. There are three dimensions of the Open System Model, flexibility \& innovation, outward focus, and reflexivity. The dimensions of flexibility \& innovation and outward focus have proven to significantly influence innovative work behavior, while the reflexivity dimension is not shown to significantly influence innovative work behavior. When a company applies flexibility and innovation, it is oriented towards better change and provides support to new ideas and more innovative approaches. This is in line with the opinion of Baer and Frese (2003) which reveal that from two dimensions of climate that play a role in the success of the innovation process in the company, one of which is a supportive organizational environment in supporting positive employee behavior towards the company. In addition, a meta-analysis study from Hammond et al. (2011) also supports the results of this study. According to them, support from the environment can improve employees' behavior in displaying innovative attitude. An environment that supports individuals to be creative and innovative or a safe environment for individuals to take risks will support individuals to contribute new ideas and try new things.

Outward focus is the level of organizational response in responding to the needs of consumers and the market in general. External focus indicates a desire to accept and transform oneself as needed. The company looks to an environment where the needs and self-adaptation are in accordance with existing demands (Patterson et al., 2005). This dimension focuses on finding information about consumer needs and matches with the characteristics of the participant's company, that is a mining company. The products are coal in large quantities, and generally this raw material is exported to other countries, especially China. Although it is less likely that interaction between employees and consumers happens, it still requires employees to remain responsive to the needs of buyers, especially with the increasing number of competitors in the sector and challenges during the pandemic.

The dimension that does not have a significant influence on innovative work behavior is reflexivity. The definition of reflexivity is a focus on reviewing goals, strategies, work processes and the wider environment. During the pandemic, with the situation requiring the company to be able to survive and operate, there is a change in priority that requires the company to focus more on production to get through this challenge. Therefore, reviewing the strategy and work process is still done but rather based on adjusting the changes rather than to completely change the condition of the organization.

The study also discusses the difference in the score of each measuring instrument based on its demographics. For organizational climate variables, there are no significant differences in the organizational climate based on demographic data. For organizational climate 
variables based on the working period, the highest average score of innovative work behavior is at the 3-10-year period (establishment stage), this difference proved to be significant. This is in line with several studies that also state that there is a significant relationship between innovative work behavior and tenure (Baumann, 2011; Etikariena, 2018; Hammond et al., 2011).

Based on their education, participants are categorized into SHS, Diploma, Bachelor, Master and Doctorate. The results of this study show the highest average score of innovative work behavior is the level of Master. The difference in average scores of innovative work behavior based on the level of education proved to be significant. This is in line with the research of Janssen (2000) and Kheng et al. (2013) which state that there are significant differences in the innovative work behavior based on education. While age has no effect, these results are different from the Pfeifer and Wagner (2012) study. This is likely due to the difference between ages that is less balanced, so it is difficult to compare.

In addition, linking with other variables or putting organizational climate in different roles would be an interesting study. A study shows that what kind of organizational climate can support a company depends also on the type of business. For example, from the research of Zubair and Manzoor (2012) found that the climate of communication within an organization had an impact on the type of advertising companies in Pakistan did. In another study, the role of organizational climate was also important, although in a different position as a mediator on leaders to become more innovative (Ahmed et al., 2019). Determining the climate of specific organization e.g., a creative organization climate (Munir \& Beh, 2019), a climate that dares to make decisions (Ye et al., 2021), therefore, conducting further studies by putting emphasis on these variables will also be able to be an alternative to further developing this research model.
This study used questionnaires that were distributed online. This was done considering the location of the company was far away, in the province of East Kalimantan and researchers were in Depok. Since it was difficult to visit the location directly, the drawback in the online questionnaire was the absence of direct supervision from researchers when participants filled out the questionnaires. Monitoring is important to minimize errors in filling out questionnaires. Therefore, the advice for further research is to go to the participant companies and directly supervise the questionnaire filling process. In this study, participants filled out questionnaires containing predictor variables and criteria at the same time. This has the potential to bring up common method variance because there is only one source in the data retrieval, self-reporting. Common method variance should be a concern because it is one of the sources of errors in measurement (Podsakoff et al., 2003). This is the reason why researchers did several procedural efforts, first by guaranteeing the anonymity of participants and second by combining items in a proactive personality gauge with two other measuring instruments and then display the item randomly. In addition, the participants' low intrinsic interest in the topic being studied, the excessive number of items, the absence of social contact during the questionnaire, and the lack of control over situational variables had the potential of making participants less attentive in working on the online questionnaires (Berry et al., 2019; Meade \& Craig, 2012). These non-attentive responses were found even though they stated voluntary participation. Thus, researchers need to examine the data on this ineffective response so that the integrity of the research can be protected.

The company participating in this study was a private mining company. The advice for further research is to look at the influence of the organizational climate on innovative work behavior in state-owned enterprises to see the difference when compared to private 
companies. It is also important to study the role of various other variables that in the previous scientific studies also play important roles, for example leadership as well as putting organizational climate on different variable roles such as being a mediator or moderator. For practical advice, the results of this study showed a significant influence of the organizational climate on innovative work behavior. This means that the corporate climate that supports creativity and innovation also supports the emergence of innovative work behavior. Therefore, if a company requires the improvement of innovative work behavior among its employees, they can design an organizational climate as mentioned above.

\section{CONCLUSION}

Based on the analysis conducted in this study, a conclusion can be made that the organizational climate can influence innovative work behavior. In addition, based on multiple regression analysis on the dimensions of the organizational climate on innovative work behavior shows that among the three dimension that is flexibility \& innovation, outward focus, and reflexivity, only two dimensions are proven to influence significantly. These two dimensions are flexibility \& innovation and outward focus. Reflexivity does not significantly influence innovative work behavior. The analysis on the innovative work behavior based on demographic data such as gender, age, tenure, education, job level, and salary, only two were shown to be of significance. These two demographics were tenure and education.

\section{REFERENCES}

Ahmed, A. A., Ata, A. A., \& Abd-Elhamid, Z. N. (2019). Relationship between the leadership behaviors, organizational climate, and innovative work behavior among nurses. American Journal of Nursing Research, 7(5), 870-878. doi: 10.12691/ajnr-7-5-20
Amabile, T. M. (1996). Creativity and innovations in organizations. Harvard Business School. https://www.hbs.edu/faculty/Pages/item.a spx?num $=13672$

Appipalakul, C \& Kummoon, D. (2017). The effects of organizational climate to conflict management amongst organizational health personnel. Procedia - Social and Behavioral Sciences, 237, 1216 - $1222 . \quad$ doi: 10.1016/j.sbspro.2017.02.192

Baer, M., \& Frese, M. (2003). Innovation is not enough: Climates for initiative and psychological safety, process innovations, and firm performance. Journal of Organizational Behavior, 24(1), 45-68. https://doi.org/10.1002/job.179

Baumann, P. K. (2011). The relationship between individual and organizational characteristics and nurse innovation behavior. [Doctoral dissertation, Indiana University]. IUPUI ScholarWorks Repository.

https://scholarworks.iupui.edu/handle/18 05/2603.

Berry, K., Rana, R., Lockwood, A., Fletcher, L., \& Pratt, D. (2019). Factors associated with inattentive responding in online survey research. Personality and Individual Differences, 149, 157-159. doi: 10.1016/j.paid.2019.05.043

Bogilović, S., Bortoluzzi, G., Cerne, M., Ghasemzadeh, K., \& Žnidaršić, J. (2020). Diversity, climate and innovative work behavior. European Journal of Innovation Management Emerald. Publishing Limited 1460-1060. doi: 10.1108/EJIM03-2020-0100

Bos-Nehles, A. C., \& Veenendaal, A. A. R. (2017). Perceptions of HR practices and innovative work behavior: The moderating effect of an innovative climate. The International Journal of Human Resource Management, 30(18), 
2662-2683.

https://doi.org/10.1080/09585192.2017.1 380680

Chang, J. C., Yang, Y. L., Chang, J. C., \& Yan, Y. L. (2012). The effect of organization's innovational climate on student's creative self-efficacy and innovative behavior. Business \& Entrepreneurship Journal, 1(1), 22412312.

http://www.scienpress.com/Upload/BEJ/ Vol\%201_1_5.pdf

Chen, Y., \& Yin, Y. (2017). Research on mechanism of innovation climate in college on college student's innovative behavior the mediating effects of intrinsic incentives. Proceedings of the $3 \mathrm{rd}$ International Conference on Arts, Design, and Contemporary Education (ICADCE 2017), Series: Advances in Social Science, Education and Humanities Research, 914-917.

17.2017 .225

Chih-Yang Chao, Yong-Shun Lin, Yu-Lin Cheng \& Yi-Chiao Tseng. (2011). Employee innovation, supervisory leadership, organizational justice and organizational culture in Taiwan's manufacturing industry. African Journal of Business Management, 5(6). https://academicjournals.org/article/articl e1380726532_Chao\%20et\%20al.pdf

Cingöz, A \& Akdoğan, A.A. (2011). An empirical examination of performance and image outcome expectation as determinants of innovative behavior in the workplace. Procedia Social and Behavioral Sciences, 24, 847853.doi:10.1016/j.sbspro.2011.09.099

De Jong, J., \& Den Hartog, D. (2010). Measuring innovative work behaviour. Creativity and Innovation Management, 19(1), 23-36. doi:10.1111/j.14678691.2010.00547.x

De Spiegelaere, S., Van Gyes, G \& Van Hootegem, G. (2014). Innovative work behavior: Concept \& measurement. Gedrag \& Organisatie, 27(2), 139-156. doi:

10.5553/GenO/092150772014027001002

Etikariena, A., \& Muluk, H. (2014). Correlation between organizational memory and innovative work behavior. Makara Human Behavior Studies in Asia, 18(2), 77. doi:10.7454/mssh.v18i2.3463

Etikariena, A. (2018). Perbedaan perilaku kerja inovatif berdasarkan karakteristik individu karyawan. Jurnal Psikologi, 17(2), 107. doi:10.14710/jp.17.2.107-118

Getz, I. \& Robinson, A. G. (2003). Innovative or die: Is that a fact? Creativity Innovation Manage, 12(3), 130-136. doi/abs/10.1111/1467-8691.00276

Hammond, M. M., Neff, N. L., Farr, J. L., Schwall, A. R., \& Zhao, X. (2011). Predictors of individual-level innovation at work: A meta-analysis. Psychology of Aesthetics, Creativity, and the Arts, 5(1), 90-105. https://doi.org/10.1037/a0018556

Hennessey, B. A., \& Amabile, T. M. (2010). Creativity. Annual Review Psychology. 61,569-598.

https://www.annualreviews.org/doi/abs/1 0.1146/annurev.psych.093008.100416

Imran, R., Saeed, T., Anis-Ul-Haq, M., \& Fatima, A. (2010). Organizational climate as a predictor of innovative work behavior. African Journal of Business Management, 4(15), 3337-3343. http://www.academicjournals.org/AJBMI zzati, U. A. (2017). The relationships between vocational high school teachers' organizational climate and innovative behavior. Proceedings of the $1 s t$ International Conference on Education Innovation (ICEI 2017). Advances in Social Science, Education and Humanities Research, 173-176. https://doi.org/10.2991/icei-17.2018.91

Janssen, O. (2000). Job demands, perceptions of effort-reward fairness and innovative 
work behaviour. Journal of Occupational and organizational Psychology, 73(3), 287-302.

https://doi.org/10.1348/09631790016703 $\underline{8}$.

Jiménez-Jiménez, D., \& Sanz-Valle, R. (2011). Innovation, organizational learning and performance. Journal of Business Research, 64(4), 408-417. doi: 10.1016/j.jbusres.2010.09.010

Józsa, K., \& Morgan, G. A. (2017). Reversed items in likert scales: Filtering out invalid responders. Journal of Psychological and Educational Research, 25(1), 7-25. http://real.mtak.hu/86132/1/Jozsa_Morga n_JPER_2017_25_1_7_25_u.pdf

Kheng, K. Y., June, S., \& Mahmood, R. (2013). The determinants of innovative work behavior in the knowledge intensive business services sector in Malaysia. Asian Social Science, 9(15), 47-59. doi:10.5539/ass.v9n15p47

Kumar, R. (2011). Research methodology: A step-by-step guide for beginners. Sage Publications Limited.

Meade, A. W., \& Craig, S. B. (2012). Identifying careless responses in survey data. Psychological Methods, 17(3), 437455. doi:10.1037/a0028085

Munir, R \& Beh, L-S. (2020). Measuring and enhacing organizational creative climate, knowledge sharing and innovative work behavior in startups development. The Bottom Line, 32(4), 269-289. https://doi.org/10.1108/BL-03-2019-0076

O'Bryan, M. (2013, November 11). Innovation: The Most Important and Overused Word in America. Wired. http://www.wired.com/2013/11/innovatio n-the-most-important-and-overusedword-in-america

Ömur, Ö. (2019). The relationship between organizational climate for innovation and employee's innovative work behavior: ICT sector in Turkey. Vezetéstudomány Budapest Management Review, 50(11). 53-64.

https://doi.org/10.14267/VEZTUD.2019. $\underline{11.04}$

Patterson, M. G., West, M. A., Shackleton, V. J., Dawson, J. F., Lawthom, R., Maitlis, S., \& Wallace, A. M. (2005). Validating the organizational climate measure: Links to managerial practices, productivity and innovation. Journal of Organizational Behavior, 26(4), 379-408.

https://doi.org/10.1002/job.312

Pfeifer, C., \& Wagner, J. (2014). Is innovative firm behavior correlated with age and gender composition of the workforce? Evidence from a new type of data for German Enterprises. Journal Labour Market Res, 47, 223-231. doi: 10.1007/s12651-013-0137-y

Podsakoff, P. M., MacKenzie, S. B., Lee, J. Y., \& Podsakoff, N. P. (2003). Common method biases in behavioral research: A critical review of the literature and recommended remedies. Journal of Applied Psychology, 88(5), 879-903. doi:10.1037/0021-9010.88.5.879

Potočnik, K., \& Anderson, N. (2016). A constructively critical review of change and innovation-related concepts: Towards conceptual and operational clarity. European Journal of Work and Organizational Psychology, 25(4), 481494. doi: 10.1080/1359432X.2016.1176022

Purwanto, D. (2013, May 2). Ini Perusahaan yang Paling Dikagumi di Indonesia. Kompas.com.

http://bisniskeuangan.kompas.com/read/2 013/05/02/10412637/Ini.Perusahaan.yang .Paling.Dikagumi.di.Indonesia

PT X. (2013). Company Profile PT X.

Quinn, R. E., \& Rohrbaugh, J. (1983). A spatial model of effectiveness criteria: 
Towards a competing values approach to organizational analysis. Management science, 29(3), 363-377.

https://doi.org/10.1287/mnsc.29.3.363

Sameer, Y. M., \& Ohly, S. (2017). Innovative behavior of employees: A model of Antecedents and Consequences, A Deeper Look at Psychological and Organizational Factors. Working Papers. 45. The German University in Cairo, Faculty of Management Technology. https://mgt.guc.edu.eg/wpapers/045Same er_2017.pdf

Scott, S. G., \& Bruce, R. A. (1994). Determinants of innovative behavior: A path model of individual innovation in the workplace. Academy of Management Journal, 37(3), 580-607. https://doi.org/10.2307/256701

Sethibe, T \& Steyn, R. (2016). Organizational climate, innovation and performance: A systematic review. Journal of Entrepreneurship \& Innovation on Emerging Economies, 2 (2). https://doi.org/10.1177/23939575166462 $\underline{87}$

Sethibe, T \& Steyn, R. (2018). The mediating effect of organizational climate on the relationship between leadership styles and their components on innovative work behavior. Journal of Entrepreneurship \& Innovation on Emerging Economies. 4(1). https://doi.org/10.1177/23939575177473 $\underline{13}$

Shalley, C. E., Zhou, J., \& Oldham, G. R. (2004). The effects of personal and contextual characteristics on creativity: Where should we go from here? Journal of Management. 30(6) 933-958. https://doi.org/10.1016/j.jm.2004.06.007

Shanker, R., Bhanugopan, R., van der Heijden, I. M., \& Farrell, M. (2017). Organizational climate for innovation and organizational performance: The mediating effect of innovative work behavior. Journal of Vocational Behavior, 100, 67-77. doi: 1016/j.jvb.2017.02.004

Standing, C., Jackson, D., Larsen, A. C., Suseno, Y., Fulford, R., \& Gengatharen, D. (2016). Enhancing individual innovation in organisations: A review of the literature. International Journal of Innovation and Learning, 19(1), 44-62. doi: 10.1504/IJIL.2016.073288

Suárez -Alvarez, J., Pedrosa, I., Lozano, L. M., García-Cueto, E., Cuesta, M., \& Muñiz, J. (2018). Using reversed items in likert scales: A questionable practice. Psicothema, 30(2), 149-158. doi:10.7334/psicothema2018.33

Sulistiawan, J., Herachwati, N., Permatasari, S. D., \& Alfirdaus, Z. (2017). The antecedents of innovative work behavior: The roles of self-monitoring. Problems and Perspectives in Management, 15(4), 263-270. doi:10.21511/ppm.15(41). 2017.10

Vinarski-Peretz, H., \& Carmeli, A. (2011). Linking care felt to engagement in innovative behaviors in the workplace: The mediating role of psychological conditions. Psychology of Aesthetics, Creativity, and the Arts, 5(1), 43-53. https://doi.org/10.1037/a0018241

Weijters, B., Weijters, B., Baumgartner, H., \& Schillewaert, N. (2013). Reversed item bias: An integrative model. Psychological Methods, 18(3), 320-334. doi: $10.1037 / \mathrm{a} 0032121$

Ye, P., Liu, L. and Tan, J. (2021). Creative leadership, innovation climate and innovation behavior: The moderating role of knowledge sharing in management. European Journal of Innovation Management, Vol. ahead-ofprint No. ahead-ofprint. https://doi.org/10.1108/EJIM-052020-0199 
Zennouche, M., Zhang, J., \& Wang, W. B. Zubair, S. A., \& Manzoor, Y. (2012). (2014). Factors influencing innovation at individual, group and organisational levels: A content analysis. International Journal of Information Systems and Change Management, 7(1), 23-42. doi:10.1504/IJISCM.2014.065052

Innovative work behavior and communication climate among employees of advertising agencies. Journal of Social Sciences. $6(1)$. 65-74. https://applications.emro.who.int/imemrf/ FWU_J_Soc_Sci/FWU_J_Soc_Sci_2012 _6_1_65_72.pdf 